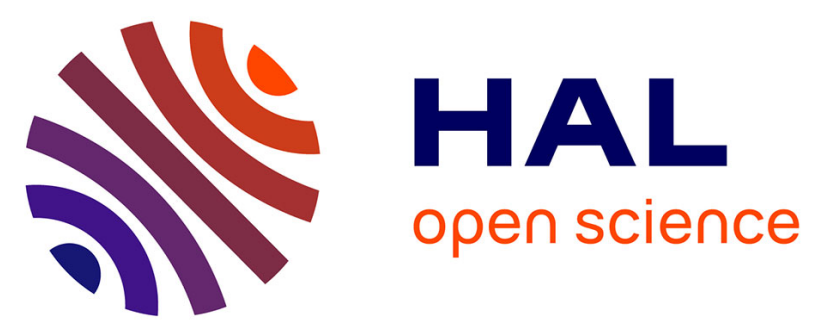

\title{
Residues of sulfadiazine and doxycycline in broiler liver and muscle tissues due to cross-contamination in the feed
}

\author{
Valerie Vandenberge, Evelyne Delezie, Gerard Huyghebaert, Philippe \\ Delahaut, Els Daeseleire, Siska Croubels
}

\section{To cite this version:}

Valerie Vandenberge, Evelyne Delezie, Gerard Huyghebaert, Philippe Delahaut, Els Daeseleire, et al.. Residues of sulfadiazine and doxycycline in broiler liver and muscle tissues due to cross-contamination in the feed. Food Additives and Contaminants, 2011, pp.1. 10.1080/19440049.2011.631194 . hal00755309

\section{HAL Id: hal-00755309 \\ https://hal.science/hal-00755309}

Submitted on 21 Nov 2012

HAL is a multi-disciplinary open access archive for the deposit and dissemination of scientific research documents, whether they are published or not. The documents may come from teaching and research institutions in France or abroad, or from public or private research centers.
L'archive ouverte pluridisciplinaire HAL, est destinée au dépôt et à la diffusion de documents scientifiques de niveau recherche, publiés ou non, émanant des établissements d'enseignement et de recherche français ou étrangers, des laboratoires publics ou privés. 


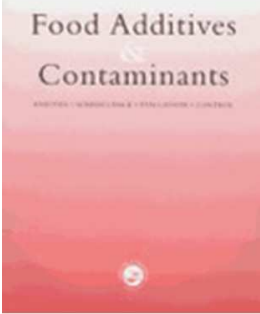

\section{Residues of sulfadiazine and doxycycline in broiler liver and muscle tissues due to cross-contamination in the feed}

\begin{tabular}{|c|c|}
\hline Journal: & Food Additives and Contaminants \\
\hline Manuscript ID: & TFAC-2011-323.R1 \\
\hline Manuscript Type: & Original Research Paper \\
\hline Date Submitted by the Author: & 30-Sep-2011 \\
\hline Complete List of Authors: & $\begin{array}{l}\text { Vandenberge, Valerie; Institute for Agricultural and Fisheries Research, } \\
\text { Technology and Food Science Unit } \\
\text { Delezie, Evelyne; Institute for Agricultural and Fisheries Research, Animal } \\
\text { Sciences Unit } \\
\text { Huyghebaert, Gerard; Institute for Agricultural and Fisheries Research, } \\
\text { Animal Sciences Unit } \\
\text { Delahaut, Philippe; Centre d'Economie Rurale, Département Santés } \\
\text { animale et humaine } \\
\text { Daeseleire, Els; Institute for Agricultural and Fisheries Research, } \\
\text { Technology and Food Science Unit } \\
\text { Croubels, Siska; Ghent University,Faculty of Veterinary Medicine, } \\
\text { Department of Pharmacology, Toxicology and Biochemistry }\end{array}$ \\
\hline Methods/Techniques: & Chromatography - LC/MS \\
\hline Additives/Contaminants: & $\begin{array}{l}\text { Veterinary drug residues - sulphonamides, Veterinary drug residues - } \\
\text { tetracycline, Veterinary drug residues - transmission }\end{array}$ \\
\hline Food Types: & Animal feed, Animal products - meat \\
\hline Abstract: & $\begin{array}{l}\text { Veterinary drugs, such as antimicrobial compounds are widely used in } \\
\text { poultry and may lead to the presence of residues in matrices of animal } \\
\text { origin such as muscle and liver tissue. In this study, broilers received } \\
\text { experimental feed, containing sulfadiazine or doxycycline at cross } \\
\text { contamination levels of } 2.5 \%, 5 \% \text { and } 10 \% \text { of the therapeutic dose in } \\
\text { feed. Breast- and thigh muscle and liver samples were collected during } \\
\text { treatment and depletion period and analyzed via liquid chromatography- } \\
\text { tandem mass spectrometry (LC-MS/MS). Concentrations reached a } \\
\text { plateau phase } 3 \text { to } 5 \text { days after starting the experimental feed. A rapid } \\
\text { depletion of residues was noted after withdrawal of the experimental feed. } \\
\text { No significant differences in measured concentrations were observed } \\
\text { between the different muscle types. The residue concentrations for some } \\
\text { experimental groups, the } 10 \% \text { group of sulfadiazine and the } 5 \% \text { and } 10 \%\end{array}$ \\
\hline
\end{tabular}



Residue Limits (MRLs).

SCHOLARONE ${ }^{\text {'M }}$

Manuscripts 
1 Residues of sulfadiazine and doxycycline in broiler liver and muscle

2 tissues due to cross-contamination of the feed

3

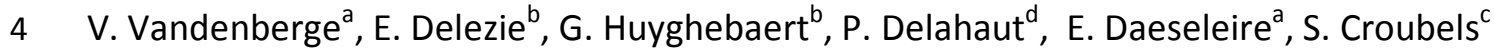

5

6

7

8

9

10

11

12

13

\section{Abstract}

Veterinary drugs, such as antimicrobial compounds are widely used in poultry and may lead to the presence of residues in matrices of animal origin such as muscle and liver tissue. In this study, broilers received experimental feed, containing sulfadiazine or doxycycline at cross-contamination levels of $2.5 \%, 5 \%$ and $10 \%$ of the therapeutic dose in feed. Breast- and thigh muscle and liver samples were collected during treatment and depletion period and analyzed via liquid chromatography-tandem mass spectrometry (LC-MS/MS). Concentrations reached a plateau phase 3 to 5 days after starting the experimental feed. A rapid depletion of residues was noted after withdrawal of the experimental feed. No significant differences in measured concentrations were observed between the different muscle types. The residue concentrations for some experimental groups, the $10 \%$ group of sulfadiazine and the $5 \%$ and $10 \%$ group of doxycycline, however exceeded the corresponding Maximum Residue Limits (MRLS).

Keywords: Residue; sulfadiazine; doxycycline; muscle; liver; feed; cross-contamination; depletion 


\section{Introduction}

The veterinary drugs used therapeutically in poultry industry are generally given via mass application in feed or drinking water (Kan and Petz 2000). Antibiotics are used to raise production efficiency, as they enhance growth and feed efficiency and reduce disease (Donoghue 2003). Antibiotics have been used as growth promoters in the member states of the EU but concerns about development of antibacterial resistance led to the withdrawal of these agents as growth promoters in the EU since January 1, 2006 (Castanon 2007). Some antimicrobial drugs, such as sulfonamides are used to treat coccidiosis (Roudaut and Garnier 2002; Sentepe and Eraslan 2010). In veterinary medicine the sulfonamides are effective chemotherapeutics for bacterial or protozoal diseases (EMEA 1995; BCFI 2010). Doxycycline belongs to the group of tetracycline antibiotics, which have a broad spectrum activity (EMEA 1996). These drugs are widely used as mass medication in both pig and poultry industry. Concerning feed medication, in Belgium, sulfadiazine in combination with trimethoprim is available as pre-mix for pigs and non-laying hens and as oral powder to be mixed in the feed of pigs. Doxycycline is registered as a premix only for pigs and also an oral powder to be mixed in the feed of pigs is available (BCFI 2010). These drugs work systemically meaning that they must cross the intestinal wall and distribute in the body to exert their function (Kan and Petz 2000). After absorption from the gastrointestinal tract, the drug reaches the blood stream and is distributed throughout the whole body. This distribution can be quantified by some pharmacokinetic characteristics such as volume of distribution, which is largely determined by the physicochemical parameters of the compounds (Kan and Petz 2000), plasma and tissue protein binding and animal physiological status (Toutain and Lees 2004).

Residues exceeding established safety tolerances may be the result of misuse of antibiotics, due to misreading of the product label or not respecting the withdrawal time or the accidental administration of feed contaminated with pharmacologically active residues (Reyes-Herrera et al. 2005; Segato et al. 2011). According to Regulation 178/2002, a feed or feeding stuff is any substance or product, including additives, whether processed, partially processes or unprocessed, intended to be used for oral feeding to animals. In Directive $2001 / 82 / E C$, a medicated feeding stuff is described as any mixture of a veterinary medicinal product or products and feed or feeds that is ready prepared for marketing and intended to be fed to animals without further processing, because of its curative, preventive or other 
properties. Medicated feeding stuffs are prepared in multi-product plants following good manufacturing practice guidelines (Segato et al. 2011). Carry-over, transfer from one production batch to the following batch may result in cross-contamination and may occur during feed processing for many reasons (Borras et al. 2011). In the EFSA reports, crosscontamination is defined as: "contamination of feeds that are produced after the production of a mixed feed, containing additives with residual amounts of the previous feed batch". Cross-contamination may be product or establishment related. Some feed additives and premixes properties; adhesive strength-adhesion to walls, particle size and density (carrier, substance) and electrostatic properties influence cross-contamination behavior and affect how cross-contamination occur. The technological equipment in the feed mill; the design of dosage and grinding and mixing equipment can influence the level of cross-contamination (EFSA 2007; Borras et al. 2011). Under practical conditions, cross-contamination of residues is unavoidable, even when preventive measures are taken (EFSA 2007). A totally risk/residue free food production system does not exist. Consequently, active surveillance and compliance programs to ensure the proper use of antibiotics and the safety of the food supply are needed (Sasanya et al. 2005). Many governments have established antibiotic residue tolerances in edible animal tissues and have determined the target tissues for residue monitoring (Reyes-Herrera et al. 2005). In the European Union, these Maximum Residue Limits (MRLs) for doxycycline for pigs and poultry are set at $100 \mathrm{\mu g} \mathrm{kg}^{-1}$ (muscle), $300 \mu \mathrm{gg}^{-1}$ (skin and fat, liver) and $600 \mu \mathrm{gg}^{-1}$ (kidneys) (EMEA 1996; BCFI 2010). For all sulphonamides, the MRL is $100 \mathrm{\mu g} \mathrm{kg}^{-1}$ in muscle, fat, liver and kidneys for all food-producing animals (AFSCA 2004; BCFI 2010). Taking into account the unavoidable cross-contamination in practical field conditions, the aims of this study were to investigate the transfer ratios of two frequently used drugs from the feed to poultry edible tissues when provided at crosscontamination levels and to evaluate this transfer in relation to current MRL's.

\section{Material and methods}

\section{Premix and oral powders, reagents and standards}

The premix containing sulfadiazine and thrimetoprim was Tucoprim ${ }^{\circledR}$ powder, kindly provided by Pfizer (Brussels, Belgium). Doxycycline oral powder to be mixed in the feed was Doxycycline $75 \% \mathrm{Kela}^{\circledR}$, kindly provided by Kela Veterinaria (Sint-Niklaas, Belgium). Analytical standards of sulfadiazine and doxycycline hyclate were from Sigma (Bornem, 
Belgium) and Acros (Geel, Belgium), respectively. The internal standards, namely sulfachloropyridazine and demethylchlortetracycline were purchased from Sigma. Acetonitrile, distilled water and methanol came from Biosolve (Valkenswaard, The Netherlands). Water was HPLC grade and generated by a Q Gard 2 system (Millipore, Billerica, MA, USA). The anhydrous sodium sulphate came from Merck (Darmstadt, Germany). Filters for filtration of the sulfadiazine extract, i.e. $0.22 \mu \mathrm{m}$ Millex ${ }^{\circledR} \mathrm{GV}$ were from Millipore (Billerica, MA, USA). The solid-phase extraction (SPE) columns used for the cleanup of doxycycline containing samples were Oasis ${ }^{\circledR}$ columns (HLB SPE column $60 \mathrm{mg} / 3 \mathrm{ml}$, Waters, Milford, MA, USA). The Robot Coupe 2, used to mince muscle and liver samples, came from C-Tech Systems (Lille, Belgium).

\section{Preparation of the experimental feed and animal experiments}

The feed preparation and the animal experiments were carried out at ILVO's Animals Sciences Unit with approval from the ILVO ethical committee (EC no. 2008/89, 2009/108).

The experimental feed was mixed with sulfadiazine or doxycycline at crosscontamination levels of $10 \%, 5 \%$ and $2.5 \%$ of the maximum allowed dose of $250 \mathrm{mg} \mathrm{kg} \mathrm{g}^{-1}$ feed for both drugs. The premix resp. oral powder was first mixed with a small amount of blank feed in the Varimixer Bear (Dehaeck construct, Ghent, Belgium), which was then added to the remaining blank feed in the feed mixer constructed by Silobouw (Zulte, Belgium). The final experimental feed was mixed at $35 \mathrm{rpm}$ during 30 minutes with a switch of direction every five minutes. Before and between the preparations of each experimental feed, rinsing batches were carried out. Ten samples were taken from the moving stream of experimental feed and from the top $(n=3)$, the middle $(n=4)$ and the bottom $(n=3)$ of each experimental feed to determine the concentration achieved and two samples of each rinsing batch were analyzed to exclude cross-contamination. Because of the large amount needed, the preparation of each experimental feed was performed in two phases.

A growth trial was set-up with 575 one-day-old broilers, male Ross 308, which were housed per concentration in a concrete floor pen under conventional conditions of ventilation, temperature and lighting (22 hours light/day). The animals were randomly assigned to three treatments, distributed among three pens and separated from each other by a narrow walkway. Each study group counted 188 chickens, of which 102 were 
123 euthanized. A small group of 11 broilers was used as control group. Each study consisted of a 124 standard 2-phase feeding including a starter and grower diet. After an adaptation period of 12512 days, experimental feed was provided during 14 days, followed by a depletion period of 12617 days, during which the animals received blank feed. The animals were given free access to 127 water and feed; they were vaccinated for Infectious Bronchitis (IB), New Castle Disease 128 (NCD) and were treated for coccidiosis. The diets were supplemented with an anticoccidial 129 (salinomycine at 60 ppm for 1-35 days) and a NSP enzyme (Ronozyme WX at 50 FXU/kg feed) but without any growth promoting antibiotic. The animals and housing facilities were inspected daily for general and individual health, sufficient feed and water supply, temperature and ventilation as well as for dead animals and unexpected events. The zootechnical parameter, chicken weight, was noted at day 10 of pre-treatment period, days $1,3,5,7,9,11,13$ of treatment period and days $1,3,5,7,9,11,13,15,17$ of post treatment period. From the age of 10 days onwards (day 10 of pre-treatment period), six animals per concentration group were slaughtered by cervical dislocation every 2 days, chicken weight was noted, breast feathers were removed and the complete breast muscles, the upper thigh muscles and the liver (without the gall-bladder) were sampled. All samples were minced and grounded with a Robot Coupe 2 and stored at $-18{ }^{\circ} \mathrm{C}$ until analysis. A pooled sample was prepared by mixing 5 to $10 \mathrm{~g}$ of every specific tissue from each of the 6 chickens.

Analysis of the breast muscle was performed every 2-days starting from day 10 of the pre-treatment period. Samples from the upper thigh muscles and the liver were only analyzed for the $10 \%$ carry-over concentration and only during steady state.

\section{Extraction and clean-up of feed samples}

145 For the analysis of sulfadiazine, $5 \mathrm{~g}$ of feed was weighed, $100 \mu \mathrm{L}$ of the internal standard sulfachloropyridazine $\left(1 \mathrm{mg} \mathrm{mL}^{-1}\right)$ was added and the sample was allowed to stand for 10 minutes. After addition of $25 \mathrm{~mL}$ of methanol, the tube was vortex mixed and afterwards placed on the horizontal shaker for 30 minutes. After centrifugation during 10 minutes at $3000 \mathrm{rpm}, 5 \mathrm{~mL}$ of the supernatant was transferred into a tube and evaporated under nitrogen to dryness in a water bath at $45^{\circ} \mathrm{C}$. After redissolving the residues in $10 \mathrm{ml}$ acetonitrile:water $\left(\mathrm{ACN}: \mathrm{H}_{2} \mathrm{O}, 50: 50\right)$, a dilution of $1: 15$ was performed in $\mathrm{ACN}: \mathrm{H}_{2} \mathrm{O}$ followed 
153 weighed and $1 \mathrm{ml}$ of the internal standard demethylchlortetracycline $\left(20 \mu \mathrm{g} \mathrm{mL}{ }^{-1}\right)$ was 154 added. After the addition of $25 \mathrm{~mL}$ of methanol, the samples were placed on a rotary shaker 155 for 20 minutes and centrifuged for $10 \mathrm{~min}$ at $4000 \mathrm{rpm}$. Two hundred $\mu \mathrm{L}$ of the supernatant 156 was transferred in a vial, $800 \mu \mathrm{L}$ of HPLC water was added and the vial was vortex mixed.

\section{Extraction and clean-up of broiler samples}

158

For sulfadiazine analysis in muscle and liver, we used the method described by Mortier et al. (2005). Two grams of minced muscle or liver were weighed and the internal standard $(20 \mu l$ of $10 \mu \mathrm{g} \mathrm{mL}^{-1}$ ) was added. The samples were vortex mixed, were allowed to stand for $10 \mathrm{~min}$ and $6 \mathrm{~g}$ (muscle) or $8 \mathrm{~g}$ (liver) of anhydrous sodium sulphate was added. The tissue was carefully mixed with a spatula until a powdery mixture was obtained and $10 \mathrm{~mL}$ (muscle) or $20 \mathrm{~mL}$ (liver) of acetonitrile was added. After vortex mixing, the tubes were placed on a horizontal shaker for $30 \mathrm{~min}$. The tubes were centrifuged (15 min, $4000 \mathrm{rpm}$ ), $5 \mathrm{~mL}$ (muscle) or $10 \mathrm{~mL}$ (liver) of the supernatant was transferred into a tube and was evaporated to dryness under nitrogen in a water bath of $45^{\circ} \mathrm{C}$. Then, the sample was redissolved in $1 \mathrm{~mL}$ of an acetonitrile/water mixture $(50: 50, v: v)$ containing $0.1 \%$ formic acid, vortex mixed, sonicated for $5 \mathrm{~min}$ and filtered through a $0.22 \mu \mathrm{m}$ filter into a HPLC vial. as described by Cherlet et al (2003). After the addition of the internal standard demethylchlortetracycline $\left(50 \mu \mathrm{l}\right.$ of $\left.10 \mu \mathrm{g} \mathrm{mL}^{-1}\right)$, the samples were vortex mixed an were allowed to stand for $5 \mathrm{~min}$. Ten $\mathrm{mL}$ of a $0.1 \mathrm{M}$ sodium succinate buffer was added, the samples were placed on a rotary shaker for 20 minutes and centrifuged at $4000 \mathrm{rpm}$ for 10 min. The supernatant was added to a centrifuge tube containing $1 \mathrm{~mL}$ of a $20 \%$ trichloroacetic acid, vortex mixed and centrifuged at $4000 \mathrm{rpm}$ for $10 \mathrm{~min}$. The supernatant was filtered through a Whatman ${ }^{\circledR}$ filter paper and was ready for a further solid-phase cleanup step. In the solid-phase clean-up, the Oasis ${ }^{\circledR}$ HLB (hydrophilic lipophilic balance) column was preconditioned consecutively with $3 \mathrm{~mL}$ methanol, $3 \mathrm{~mL}$ of a $1 \mathrm{~N} \mathrm{HCl}$ solution and $3 \mathrm{~mL}$ of water and the extract was allowed to pass slowly through the HLB column. The HLB column was washed with $1 \mathrm{~mL}$ of water and dried. The analytes were eluted with $3 \mathrm{~mL}$ of methanol and the eluate was evaporated to dryness at $40{ }^{\circ} \mathrm{C}$ under nitrogen. After redissolvation with $250 \mu \mathrm{L}$ of a $0.5 \%$ formic acid solution and vortex mixing, the sample was transferred to an autosampler vial. 
184

185

186

187

188

189

190

191

192

193

194

195

196

197

198

199

200

201

202

203

204

205

206

207

208

209

210

211

212

213

\section{LC-MS/MS analysis}

The sulfadiazine analysis was performed on a Waters Alliance 2695 Separation Module combined with a Waters Micromass Quattro MS instrument. An X-terra ${ }^{\circledR}$ column $\left(C_{18} 5 \mu \mathrm{m}\right.$, $150 \times 2.1 \mathrm{~mm}$ ) was used and the analysis was performed with a gradient of $0.1 \%$ formic acid (FA) in $\mathrm{H}_{2} \mathrm{O}$ (solvent $\mathrm{A}$ ) and $0.1 \% \mathrm{FA}$ in $\mathrm{ACN}$ (solvent $\mathrm{B}$ ). The analysis of doxycycline was performed on a Waters Alliance 2695 Separation Module combined with a Waters Micromass Quattro Ultima MS instrument. Separation was performed on a PLRP-S polymer column ( $5 \mu \mathrm{m}, 150 \times 2.1 \mathrm{~mm}$ ). An isocratic mobile phase consisting of $70 \%$ solvent A (HPLC $\mathrm{H}_{2} \mathrm{O}+0.5 \%$ formic acid and $0.001 \mathrm{M}$ oxalic acid; $0.5 \%$ tetrahydrofurane) and $30 \%$ of solvent $B(A C N)$ was used. The analysis of sulfadiazine and doxycycline was performed in MRM mode and electrospray positive ion mode (sulfadiazine: $\mathrm{m} / \mathrm{z} 250.94$-> 107.95, 250.94 -> 92.18, 250.94 -> 156.06; doxycycline: $m / z 462.45$-> 428.1). In this study, the limit of quantification (LOQ) of the method was $5 \mathrm{mg} \mathrm{kg}^{-1}$ and $2.5 \mathrm{mg} \mathrm{kg}^{-1}$ for sulfadiazine and doxycycline respectively for feed. For muscle and liver, the method LOQ was 2 and $10 \mu \mathrm{gg}^{-1}$ for sulfadiazine and doxycycline.

\section{Pharmacokinetic and statistical analysis}

These studies were not repeated, therefore, no statistical analysis of the effect of the experimental feed on the zootechnical parameters was performed. Due to the limited dataset of the experimental feed, no statistical analysis to determine the homogeneity of the experimental feeds could be carried out. The terminal elimination half-life and elimination rate constant in tissues were calculated using pharmacokinetic (PK) functions for Excel and were based on the terminal slope of the tissue concentration-time curve after withdrawal of the experimental feed (Usansky et al, Allergan, Irvine, USA). Statistical analysis was performed with Statistica 9.0 (StatSoft. Inc., Tulsa, OK, USA). Significance level $\alpha$ was set at 0.05. Statistical analysis was performed on the mean of the residue concentrations of the individual chickens and the pooled sample for each of the different matrices. The comparison between measured residue concentrations in thigh muscle and in breast muscle was performed with a t-test for dependent samples. The pooled sample on day 13 of treatment period was analysed six times. The mean of these results was compared with the mean of the individual chickens by an independent t-test. 


\section{Zootechnical parameters and experimental feed}

216 The effects of experimental feed on the performance parameter, broiler weight, were 217 studied. The mean broiler weights are presented for sulfadiazine and doxycycline in Figure 1.

For both sulfadiazine and doxycycline the maximum authorized dose is $250 \mathrm{mg} \mathrm{kg}^{-1}$ (instruction leaflets). Therefore a value of $25,12.5$ and $6.25 \mathrm{mg} \mathrm{kg}^{-1}$ was calculated for the 10 $\%, 5 \%$ and $2.5 \%$ carry-over groups, respectively. Mean concentrations \pm standard deviation and recovery for the $10 \%, 5 \%$ and $2.5 \%$ groups were $21.2 \pm 1.8(79 \%), 12.7 \pm 0.9(93 \%)$ and $5.5 \pm 0.4(88 \%) \mathrm{mg} \mathrm{kg}^{-1}$ for sulfadiazine and $24.7 \pm 4.6(99 \%), 13.2 \pm 4.1(106 \%), 5.5 \pm$ $1.2(88 \%) \mathrm{mg} \mathrm{kg}^{-1}$ for doxycycline.

Residue concentrations in breast muscle, thigh muscle and liver

225

The residue concentrations for respectively sulfadiazine and doxycycline for all groups in breast muscle are shown in Figure 2. The plateau phase was reached at day 3 for all dietary treatments of the doxycycline and the 2.5 and $5 \%$ carry over group of sulfadiazine. A rapid depletion phase was noted after withdrawal of the experimental feed. The breast muscle tissue elimination half-life was calculated for both molecules but due to the rather fast decline below the LOQ, elimination half-life could only be calculated for the 5 and $10 \%$ group of doxycycline, namely 3.1 and 3.5 days, respectively. The concentrations in the three tissue matrices for the $10 \%$ group during plateau phase are presented in Figure 3. Small differences in concentrations were noted between the different types of muscles for sulfadiazine as well as for doxycycline but these were not statistically significant. Measured residue concentrations in liver were similar from the concentrations in muscle for sulfadiazine although higher concentrations were measured in liver compared to muscle for doxycycline. The ratio liver/breast muscle was 1.2 and 1.8; the ratio liver/thigh muscle was 1.3 and 1.9 for sulfadiazine and doxycycline respectively. Transfer factors,

$\frac{\text { concentration in the matrix on day } 13 \text { of treatment period for the } 10 \% \text { group }}{\text { measured concentration in the feed }}$

241 Transfer factors of breast muscle, thigh muscle and liver were 1.04, 0.95 and $1.37 \%$ for sulfadiazine and $1.27,1.62$ and $2.90 \%$ for doxycycline. 
The measured residue concentrations of the tissues from the 6 individual chickens and the six repetitive analyses' of the pooled sample were compared. The calculated means and standard deviations are presented in Table 1. For both molecules no significant difference between the 2 means was noted for all matrices ( $P>0.05)$.

\section{Discussion}

For the experimental feed of sulfadiazine and doxycycline, the target concentrations of $2.5,5$ and $10 \%$ of the maximum allowed dose were reached $(79-106 \%)$ but no statements can be made about the homogeneity of the experimental feeds. The achievement of adequate mixing of an active ingredient in final feed depends on the composition of the final feed, the precision and the size of samples taken for analysis and other factors such as particle size, electrostatic properties, types of mixing machinery and mixing in stages or trituration (EMEA 1996). The ideal way to mix a drug is to add it at the beginning of the pre-mix process just prior to pelleting (Daniel 2009). Good sampling requires sufficient samples of adequate size and sampling from a moving stream is better than static sampling (Borras et al. 2011). Since very small volumes of pre-mixes were added to large amounts blank finished feed and because the experimental feed differs in composition from the feed used for target species for which the medicated pre-mix is intended, it is not easy to guarantee a homogeneous feed. For each experimental feed, ten dynamic samples were taken after 30 min of mixing at the top $(n=3)$, the middle $(n=4)$ and the bottom $(n=3)$ of the final feed in order to provide as good as possible sampling procedure.

For both compounds studied, no significant differences were found between the concentrations in breast and thigh muscle. Most of the sampling occasions, the residue concentrations in breast muscle were slightly higher compared to the concentrations in thigh muscle. For doxycycline, this was confirmed by Atef et al. (2002) while Reyes-Herrera et al. (2005, 2008) found significantly higher concentrations of enrofloxacin in breast muscle compared to thigh muscle but no difference in concentrations between different breast sections (Reyes-Herrera et al, 2005; Reyes-Herrera et al, 2008). Other authors reported differences between residual concentrations in thigh and breast muscle, which may be explained by a different amount of intramuscular fat content. According to Reyes-Herrera, different antibiotics may have different sites of preferential deposition and therefore it may 
be interesting to determine the edible tissue with the highest concentration if the target tissue is muscle (Reyes-Herrera et al. 2005). Elimination half-lives were calculated for breast muscle. Atef et al. (2002) found an elimination half-life of 1.8 days for breast muscle in contrast to our calculated value of 3.1 to 3.5 days. This difference may be due to the different ways of oral administration and the duration of the administration, a dose of 15 $\mathrm{mg} / \mathrm{kg}$ was provided orally twice daily during 5 successive days. Doxycycline had higher residue concentrations in the liver compared to muscle as reflected by the feed/tissue transfer ratio's, which has also been described by other researchers (Atef et al. 2002; Ismail and El-Kattan 2004). Doxycycline is known to be well absorbed from the gastro-intestinal tract (Yoshimura et al. 1991), to have a high volume of distribution with the highest detected levels in liver and kidney (EMEA 1996) and to have a high tissue binding (Santos et al. 1997). Doxycycline has an absolute oral bioavailability of $73.4 \%$ and may be metabolised up to 40 $\%$ by the liver and is largely excreted in faeces, via bile (EMEA 1996; Laczay et al. 2001). After oral dosing, a good bioavailability (approximately $80 \%$ ) of sulfadiazine is obtained in nonfasted chickens (Baert et al. 2003). Sulphonamides may be metabolized in various tissues, mainly the liver at varying degrees and through varying mechanisms such as acetylation and oxidation and are mainly excreted via the kidneys (Sentepe and Eraslan 2010).

In this study, besides individual tissue analysis we also analyzed a pooled sample. We may conclude that pooled tissue samples are a good reference for the mean of the 6 individual chickens for the studied matrices. An important remark is the animal dependent variability, noted for each of the different matrices. This needs to be kept in mind while sampling and interpreting the results in case of a cross contamination problem occurs on a farm.

For muscle, MRL's have been set at $100 \mu \mathrm{g} \mathrm{kg}^{-1}$ for sulfadiazine as well as for doxycycline (BCFI 2010). The $10 \%$ group of sulfadiazine and the 5 and $10 \%$ group of doxycycline generated concentrations above the MRL, whereas intake of $5 \%$ carry-over of sulfadiazine and the $2.5 \%$ of doxycycline resulted in concentrations around the MRL. Only the $2.5 \%$ group of sulfadiazine generated concentrations that were below the MRL. For liver, MRL'-s have been set at $100 \mu \mathrm{g} \mathrm{kg}^{-1}$ and $300 \mu \mathrm{g} \mathrm{kg}^{-1}$ for sulphonamides and doxycycline resp. (BCFI 2010). Only liver tissue from the animals receiving the $10 \%$ concentration in feed was analyzed and resulted in concentrations exceeding the MRLs. It may be concluded that 
304 cross-contamination may lead to the presence of residual concentrations above MRL. 305 However, once the "cross-contaminated feed" was no longer administered, we observed a

306

307

308

309

310

311

312

313

314

315

316

317

318

319

320

321

322

323

324

325

326

327

328

329

330

331

332

333

fast decline in measured concentrations.

The use of cross-contaminated feed may have several consequences for animal as well as human health. Besides the possible adverse effect on the health of non-target species and the indirect toxic effect by the promotion of resistant strains of bacteria, the MRL may also be exceeded in food matrices of animal origin, and consequently food safety may not be guaranteed (Donoghue et al. 1997; Segato et al. 2011; Vincent et al. 2011). These experiments indicate that important residual levels of both molecules occur in both muscle and liver after feeding cross-contamination levels. An unaware farmer, who provides feed accidentally contaminated with pharmacologically active residues to his animals, may also face legal repercussions because of exceeding the MRL in matrices of animal origin. However, the problem of residual concentrations due to the use of cross-contaminated feed can be resolved within days after switching to blank feed since both molecules showed quick residue depletion once the experimental feed was no longer administered.

\section{Acknowledgements}

Special thanks go to our lab personnel; namely P. De Neve, P. Van Herreweeghe, E. Verween, L. Batjoens and S. Degroote of ILVO's, Technology and Food Science Unit and to A. Maes and M. Geerinck of Ghent University for their help with the LC-MS/MS analyses. Also thanks to the animal care takers; B. Claeys, M. De Cock, J. De Deken, A. De Ruyver, D. Derore, C. Eeckhout and G. Van Den Bossche of ILVO's Animal Sciences Unit for their help with the animal experiments, to $M$. Levenson for language correction.

\section{References}

AFSCA. 2004. Advies 24-2004: "Actielimieten voor de aanwezigheid van residuen van bepaalde additieven en bepaalde diergeneesmiddelen in levensmiddelen wanneer er geen maximumwaarde voor residuen (MRL) is en waarboven maatregelen moeten worden getroffen ter vrijwaring van de veiligheid van de voedselketen." (SciCom2004/24). [Internet]. 2004. Federaal Agentschap voor de Veiligheid van de Voedselketen; [cited 2004]. www.afsca.be/home/com-sci/doc/avis04/Advies_2004-24.pdf 
Atef M, Youssef SAH, El-Eanna HA, El-Maaz AA. 2002. Influence of aflatoxin B1 on the kinetic disposition, systemic availability and tissues residues of doxycycline in chickens. Br Poult Sci. 43 (4): 528-532.

337

Baert K, De Baere S, Croubels S, De Backer P. 2003. Pharmacokinetics and oral bioavailability of sulfadiazine and thrimetoprim in broiler chickens. Vet Res Commun. 27: 301-309.

Borras S, Companyo R, Granados M, Guiteras J, Perez-Vendrell AM, Brufau J, Medina M and Bosch J. 2011. Analysis of antimicrobial agents in animal feed. Trends Analyt Chem. 30(7): 1042-1064.

342

BCFI. 2010. Gecommentarieerd Geneesmiddelenrepertorium voor Diergeneeskundig gebruik. Brussel. Belgisch Centrum voor Farmacotherapeutische Informatie.

344 Castanon JIR. 2007. History of the use of antibiotic as growth promoters in European poultry feeds. Poult Sci. 86: 2466-2471.

Cherlet M, Schelkens M, Croubels S, De Backer P. 2003. Quantitative multi-residue analysis of tetracyclines and their 4-epimers in pig tissues by high-performance liquid chromatography combined with positive-ion eclectrospray ionization mass spectrometry. Anal Chim Acta. 492: 199-213.

Daniel P. 2009. Drugs and chemicals in aquafeeds: The problems and solutions. Options Méditerranéennes A. 86: 85-94.

352 Donoghue DJ, Hairston H, Henderson M, Mcdonald M, Gaines S, Donoghue AM. 1997. 353 Modeling drug residue uptake by eggs: Yolks contain ampicillin residues even after drug 354 withdrawal and nondetectability in the plasma. Poult Sci. 76: 458-462.

Donoghue DJ. 2003. Antibiotic residues in poultry tissues and eggs: Human health concerns? 356 Poult Sci. 82: 618-621.

357 European Commission. 2001. Directive 2001/82/EC of the European parliament and of the 358 Council on the community code relating to veterinary medicinal products. Off. J. Eur. Union. 359 L311: 1-66. 
360 European Commission. 2002. Regulation (EC) No 178/2002 of the European parliament and 361 of the Council laying down the general principles and requirements of food law, establishing 362 the European Food Safety Authority and laying down procedures in matters of food safety. 363 Off. J. Eur. Union. L31: 1-24.

364 EMEA. Committee for veterinary medicinal products sulfonamides (2) summary report 365 [Internet]. 1995. London (UK): The European Agency for the Evaluation of Medicinal 366 products veterinary Medicines Evaluation Unit; [cited 1995].Available 367 from:http://www.ema.europa.eu/

368 EMEA. Committee for veterinary medicinal products doxycycline hyclate summary report 369 [Internet]. June 1996. London (UK): The European Agency for the Evaluation of Medicinal 370 Products Veterinary Medicines Evaluation Unit; [cited 1996 Jun]. Available 371 from:http://www.ema.europa.eu/

372 EMEA. Additional Quality requirements for products intended for incorporation into animal 373 feedingstuffs (medicated premixes). [Internet]. December 1996. London (UK): The european 374 agency for the Evaluation of Medicinal Products Veterinary Medicines Evaluation Unit; [cited 3751996 Dec]. Available from:http://www.ema.europa.eu/.

376 EFSA. Cross-contamination of non-target feedingstuffs by lasalocid authorised for use as a 377 feed additive. [Internet].2007. The European Food Safety Authority Journal; [cited 2007 Sept 378 20]. Available from: http://www.efsa.europa.eu/

379

380

381

382

383 384

385 386

Ismail MM, El-Kattan YA. 2004. Disposition kinetics of doxycycline in chickens naturally infected with Mycoplasma gallisepticum. Br Poult Sci. 45(4): 550-556.

Kan CA, Petz M. 1999. Residues in veterinary drugs in eggs and their distribution between egg white and yolk. Paper presented at: Symposium on Agrochemical Residues in Eggs. National Meeting of the American-Chemical-Society; 1999; New Orleans, Louisiana.

Kan CA and Petz M. 2000. Residues of veterinary drugs in eggs and their distribution between yolk and white. J Agric Food Chem. 48(12):6397-6403. 
Laczay P, Semjén G, Lehel J, Nagy G. 2001. Pharmacokinetics and bioavailibilty of doxycycline 388 in fasted and non fasted broiler chickens. Acta Vet Hubg. 49 (1):31-7.

389

Mortier L, Daeseleire E, huyghebaert G, Grijspeerdt K, van Peteghem C. 2005. Detection of

390

residues of the coccidiostat diclazuril in poultry tissues by liquid chromatography-tandem

391

mass spectrometry after withdrawal of medicated feed. J Agric Food Chem. 53:905-911.

392

393

Reyes-Herrera I, Schneider MJ, Cole K, Farnell MB, Blore PJ, Donoghue DJ. 2005. 394 Concentrations of antibiotic residues vary between different edible muscle tissues in poultry. 395 J Food Prot. 68 (10): 2217-2219.

396

Sasanya JJ, Okeng JWO, Ejobi F, Muganwa M. 2005. Use of sulfonamides in layers in Kampala 404 district, Uganda and sulfonamide residues in commercial eggs. Afr Health Sci 5 (1): 33-39.

Segato G, Benett C, Angeletti R, Montesissa C, Biancotto G. 2011. Doxycycline and 
409 Toutain PL, Lees P. 2004. Integration and modelling of pharmacokinetic and 410 pharmacodynamic data to optimize dosage regimens in veterinary medicine. J Vet 411 Pharmacol Ther. 27(6):467-477.

412 Usansky JI, Desai A, Tang-Liu D. PK functions for Microsoft Excel. Department of 413 Pharmacokinetics and Drug Metabolism. Allergan, Irvine, CA 92606, USA.

414 Vincent U, Ezerskis Z, Chedin M, von Holst C. 2011. Determination of ionophore coccidiostats 415 in feeding stuffs by liquid chromatography-tandem mass spectrometry. Part II. Application to 416 cross-contamination levels and non-targeted feed. J Pharm Biomed Anal. 54: 526-534

417 Yoshimura H, Osawa N, Rasa FSC, Hermawati D, Werdiningsih S, Isriyanthi NMR, Sugimori T. 418 1991. Residues of doxycycline and oxytetracycline in eggs after medication via drinking 419 water to laying hens. Food Addit Contam. 8 (1):65-69.

420

421

\section{Tables}

422 Table 1: Mean and standard deviation ( $\mu \mathrm{g} \mathrm{kg}^{-1}$ ) of the pooled sample and the six individual 423 chickens on day 13 of the treatment period.

\section{Figures}

426 Figure 1: Mean broiler weight ( $n=6 /$ conc. group) of the 3 concentration groups of the 427 sulfadiazine and doxycycline study during pre-treatment period (day 1 -> day 12 included), 428 treatment period (day 13 -> day 26 included) and depletion period (day 27 -> day 43 ).

429 Figure 2: Residue concentrations of the 3 sulfadiazine and doxycycline concentration groups $430(2.5 ; 5$ and $10 \%)$ in the breast muscle during treatment period (day $1->$ day 14 included) 431 and depletion period (day 15 -> day 31 ).

432 Figure 3: Residue concentration in breast muscle, thigh muscle and liver for sulfadiazine 10\% 433 and doxycycline $10 \%$ during treatment period (day $5 \rightarrow$ day 14 included) and depletion 434 period (day 15). 


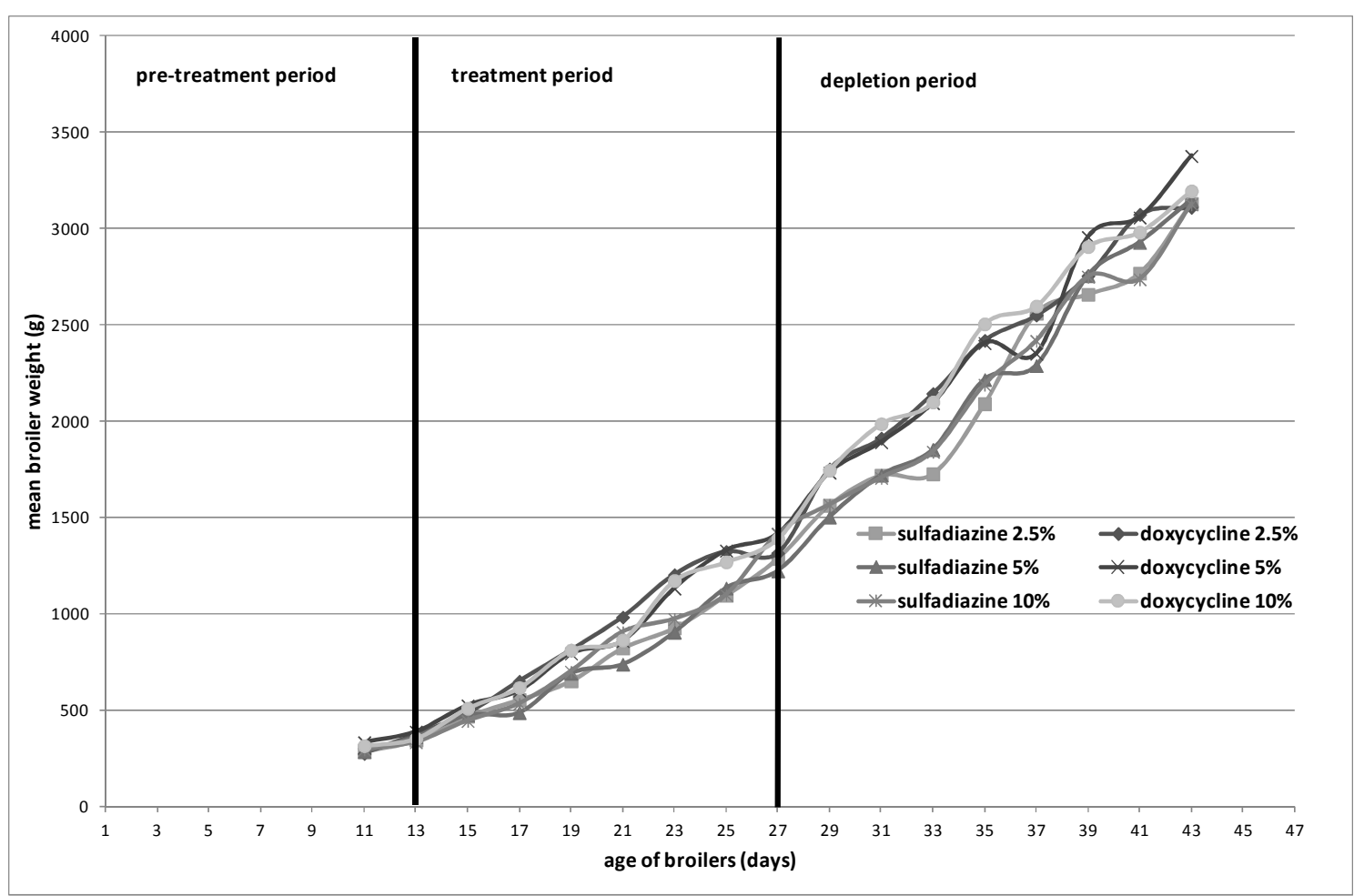




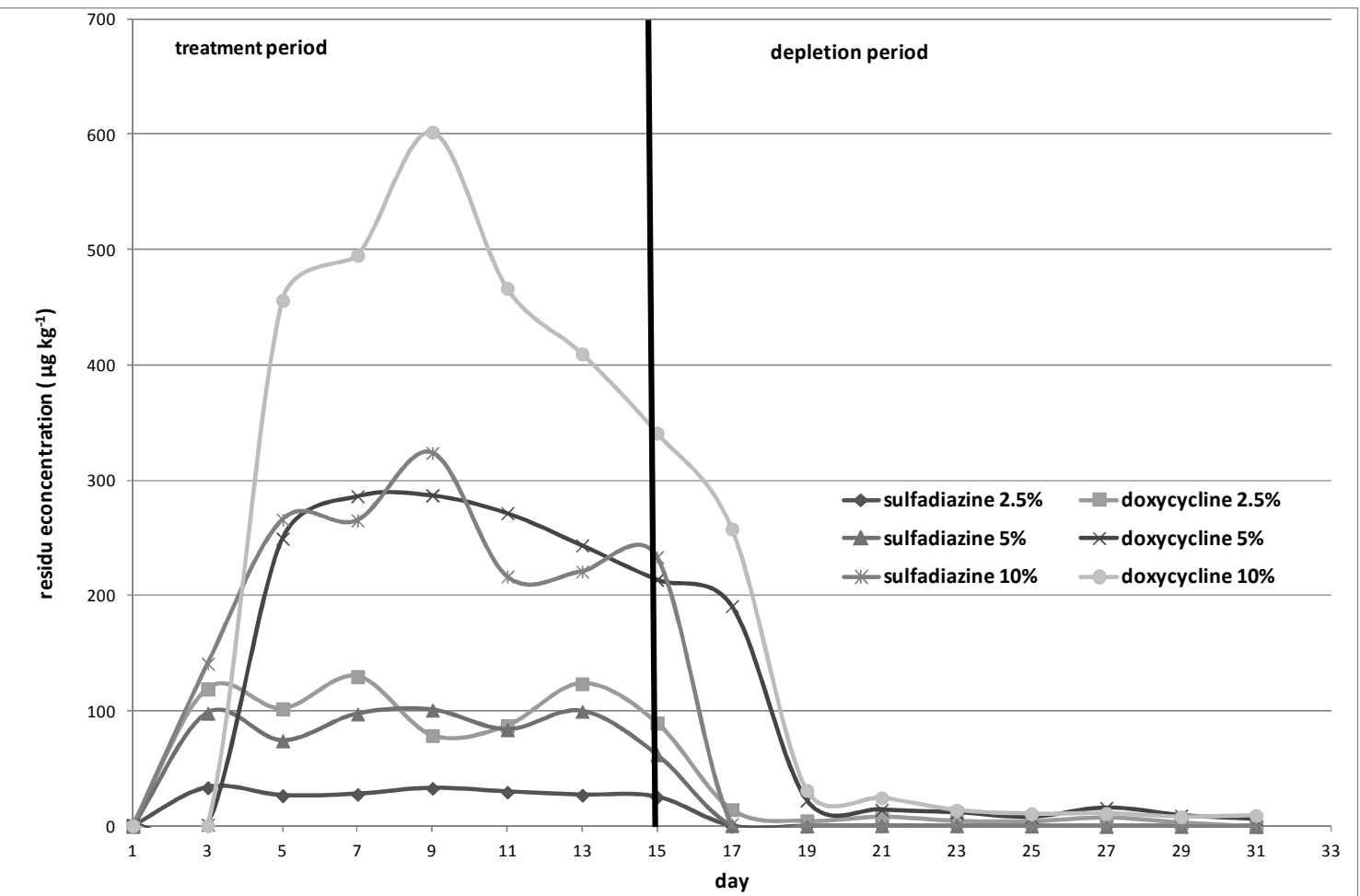


1

2

3

4

5

6

7

8

9

10

11

12

13

14

15

16

17

18

19

20

21

22

23

24

25

26

27

28

29

30

31

32

33

34

35

36

37

38

39

40

41

42

43

44

45

46

47

48

49

50

51

52

53

54

55

56

57

58

59

60

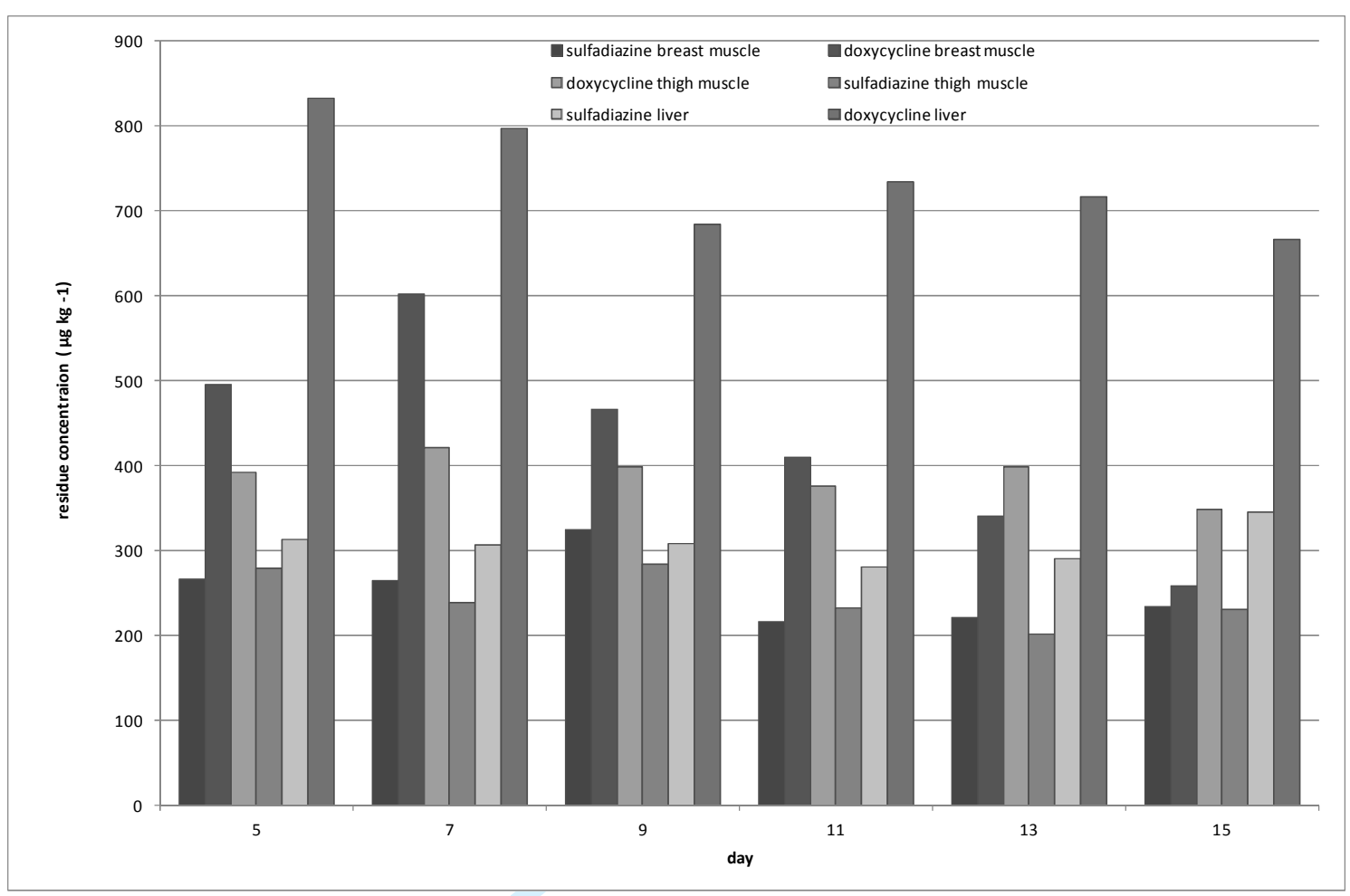

http://mc.manuscriptcentral.com/tfac Email: fac@tandf.co.uk 


\begin{tabular}{|c|c|c|c|}
\hline Molecule & Sample type & Matrix & $\begin{array}{l}\text { Mean and standard } \\
\text { deviation }\left(\mu \mathrm{gg}^{-1}\right)\end{array}$ \\
\hline \multirow[t]{6}{*}{ Sulfadiazine } & \multirow{3}{*}{$\begin{array}{l}\text { Six analyses of } \\
\text { the pooled } \\
\text { sample }\end{array}$} & Breast muscle & $201.6 \pm 15.7$ \\
\hline & & Thigh muscle & $172.2 \pm 7.7$ \\
\hline & & Liver & $358.0 \pm 20.4$ \\
\hline & \multirow{3}{*}{$\begin{array}{l}\text { Analysis of six } \\
\text { individual } \\
\text { chickens }\end{array}$} & Breast muscle & $202.6 \pm 49.8$ \\
\hline & & Thigh muscle & $173.1 \pm 30.3$ \\
\hline & & Liver & $355.8 \pm 109.0$ \\
\hline \multirow[t]{6}{*}{ Doxycycline } & \multirow{3}{*}{$\begin{array}{l}\text { Six analyses of } \\
\text { the pooled } \\
\text { sample }\end{array}$} & Breast muscle & $485.7 \pm 88.8$ \\
\hline & & Thigh muscle & $344.4 \pm 13.3$ \\
\hline & & Liver & $728.4 \pm 74.4$ \\
\hline & \multirow{3}{*}{$\begin{array}{l}\text { Analysis of six } \\
\text { individual } \\
\text { chickens }\end{array}$} & Breast muscle & $474.8 \pm 107.5$ \\
\hline & & Thigh muscle & $327.7 \pm 32.7$ \\
\hline & & Liver & $726.2 \pm 74.7$ \\
\hline
\end{tabular}

1 